\title{
Pre-Primary Education of Roma Children in Serbia: Barriers and Possibilities
}

SunČica MaCURA-Milovanović ${ }^{1}$

$\approx$ In Serbia, as in the other countries of the Western Balkans and South-Eastern Europe, the most disadvantaged communities belong to the Roma minority. The present paper demonstrates the conditions of Roma preschool children in Serbia: primarily their early education, but also habitation and health in Roma settlements. The data highlight the under-representation of Roma children in pre-primary education, although their growing up in extremely deprived settlements would suggest a need for their earliest possible inclusion in pre-primary services. The paper analyses the following barriers to the access of Roma children to the system of pre-primary education: the poverty of Roma families; discrimination and prejudice towards Roma; the lack of intercultural provision; insufficient inter-sectorial cooperation; the underdeveloped network of preschool institutions; and the absence of kindergartens in Roma settlements. In addition, possible ways to increase the coverage of Roma children in pre-primary education are discussed. As a transitory solution, the paper proposes comprehensive community-based programmes that could contribute to the education, care, health and overall development of young Roma children before their inclusion in desegregated programmes in preschool institutions.

Keywords: Roma children; Pre-primary education; Comprehensive community-based programmes; Serbia

1 Faculty of Education in Jagodina, University of Kragujevac, Serbia suncicamacura@gmail.com 


\section{Predšolska vzgoja romskih otrok v Srbiji: ovire in možnosti}

SunČica Macura-Milovanović

$\propto$ V Srbiji in tudi drugih državah vzhodnega Balkana in jugovzhodne Evrope je romska skupnost ena najbolj deprivilegiranih. Prispevek obravnava razmere romskih predšolskih otrok v Srbiji - primarno njihovo zgodnejše izobraževanje, ob tem pa tudi bivanjske in zdravstvene razmere v romskih naseljih. Podatki kažejo, da je število romskih otrok, ki so vključeni v predšolsko vzgojo, zelo nizko, čeprav bi - glede na to, da odraščajo v močno nespodbudnem okolju - potrebovali čim hitrejšo vključitev v predšolske ustanove. Prispevek analizira naslednje ovire, ki otežujejo vključitev romskih otrok v sistem predšolske vzgoje: revščina romskih družin, diskriminacija in predsodki pred Romi, pomanjkanje medkulturnih predpisov, pomanjkljivo sodelovanje med ustanovami, nerazvita mreža predšolskih ustanov in odsotnost vrtcev v romskih naseljih. Prispevek obravnava tudi mogoče rešitve za povečanje vključenosti romskih otrok v predšolsko vzgojo. Kot prehodna rešitev so $\mathrm{v}$ prispevku predlagani obsežni javni programi, ki bi lahko prispevali $\mathrm{k}$ izobrazbi, negi, zdravju in k celostnemu razvoju romskih otrok še pred vključitvijo v vključujoče programe predšolske vzgoje.

Ključne besede: romski otroci; predšolska vzgoja; celostni programi za skupnost; Srbija 


\section{Introduction}

Research-based literature clearly shows that high quality pre-primary education, e.g., early childhood care and education (ECCE) (an international phrase that emphasises the continuum of education and care needed for young children) does benefit children in the long term, particularly the most disadvantaged children. Therefore, ECCE is explicitly defined "as an effective means to establish the basis for further learning, preventing school drop-out, increasing equity of outcomes and overall skill levels" (Eurydice, 2009).

There are, however, some intermediary factors that influence the effects of ECCE. For example, it must begin as early as possible: at age two or three (Eurydice Network, 2009; Sylva et al., 2004). Also, high quality ECCE provided on a large scale (in a sufficient 'dose') forces the emergence of certain school skills in the areas of language, literacy, maths and science, as well as supporting the development of young children's learning-related social-emotional skills, in particular self-regulation and social competence (McClelland et al., 2006). If ECCE programmes are expanded by incorporating strategies to work with parents and families in order to support and empower them, the effect on IQ and school achievement is stronger and more durable. In addition, there are positive effects on social-emotional levels, such as better self-esteem, work attitude and sociability (Leseman, 2009).

A systematic review of longitudinal cost-benefit studies of early interventions, presented in Early Childhood and Care Education: Key lessons from research to policy makers (European Commission (EC), 2009), identified three major US studies that demonstrate a significant influence on children's development and further education: the Perry HighScope, the Abecedarian, and the Chicago Child-Parent Centres. These programmes were carried out in the 1960s, 1970s and 1980 s and in ghettoised areas with mostly African-American and Hispanic children. Each of the studies reported significant longitudinal outcomes of the respective intervention.

The Perry HighScope study, for example, monitored 123 high-risk African-American children from ages three to four through the period 1962-1967, after they had been divided into one group participating interactively in daily preschool with weekly involvement with the family and a second (control) group that had no intervention. At the age of 40 years, the adults who had been in the pre-primary programme had higher earnings, were more likely to hold a job, had committed fewer crimes, and were more likely to have graduated from high school than those who had been in the control group (HighScope, 2004). The Chicago study also reported a significant difference in juvenile crime rates 
between the intervention and the control group (EC, 2009).

More recently, the effects of ECCE programmes were studied longitudinally in the UK, with a sample of approximately 3,00o preschool-aged children (Sylva et al., 2004). The experimental groups of children attended diverse early education programmes for various lengths of time, while the control group did not attend early education. Study results show that the duration of early education attendance and the timing of commencement (at or before three years) are related positively to better intellectual development. Early education also fosters children's independence, concentration and sociability, evidenced not only at entry to school but also at the end of the second year in school. One conclusion of the study is that disadvantaged children can benefit from high quality early education, particularly in socially mixed groups (Sylva et al., 2004).

The characteristics of the most effective ECCE programmes could be summarised as follows: they are intensive, early starting (as early as possible, preferably at age two or three), child-focused, centre-based (rather than home-based), with strong parental involvement, parent education, educational home activities and measures for family support (Eurydice, 2009).

In addition to the benefits of ECCE programmes for the development and further education of disadvantaged children, they are also of vital importance for the progress of any country and its economic development. Investment in the coverage of young children with quality ECCE programmes decreases the costs of compensatory and special education, social spending and criminal court costs; furthermore, it increases incomes and taxes paid, and has significant positive effects on the economy of a country due to the increase of GDP through the improved competencies of manpower (Lynch, 2005). In comparison with other measures to stimulate economic growth, investment in quality ECCE has significantly stronger and longer lasting effects. This is why the complete coverage of three- and four-year-olds in ECCE is one of the priorities in developed countries (Ivić, Pešikan, \& Jankov, 2010).

The general accessibility of high quality pre-primary education can be particularly important for the mitigation of inequalities caused by factors such as the low educational level of parents, the difference in language that the child speaks at home and the language of instruction at school, and parents' socioeconomic status (Ivić, Pešikan, \& Jankov, 2010). The Nobel Prize laureate Heckman has argued that high quality early childhood education and care provides one of the few effective policy means of increasing social and economic opportunities for disadvantaged communities, and, therefore, for society as a whole (Heckman, 2006).

In Serbia, as in the other countries of the Western Balkans and SouthEastern Europe, the most disadvantaged communities belong to the Roma 
minority (Save the Children, 2001). The present paper demonstrates the conditions in which preschool Roma children live in Serbia: primarily their early education, but also habitation, health and development in Roma settlements. The data highlight the under-representation of Roma children in pre-primary education, although their growing up in extremely deprived settlements, such as slums, would suggest a need for their earliest possible inclusion in pre-primary ${ }^{2}$ services. The paper analyses barriers to the access of Roma children to the system of preprimary education and aims to answer the following question: What are the possibilities for enhancing the inclusion of Roma children in pre-primary education?

The paper draws on the Roma Early Childhood Inclusion (RECI) Overview Report based on research conducted under the leadership of Dr John Bennett. The research was conducted in the Czech Republic, Romania, Serbia, and the Former Yugoslav Republic of Macedonia, and was jointly funded by the Open Society Foundations, the Roma Education Fund and UNICEF. The RECI Overview Report (Bennett, 2012) is an interpretative summary of the four national reports. The author of the present paper participated in the RECI project as one of the researchers and writers of the national report for Serbia.

\section{Roma Children in Serbia}

The Roma are the poorest and most vulnerable social group, living on the margins of society: $60.5 \%$ of the Roma population falls within the category of "very poor", compared with $6.1 \%$ of the average population (UNICEF, 2007). According to the last census, taken in 2011 (Statistical Office of the Republic of Serbia, 2011), there are 147,604 Roma in Serbia, representing $2.05 \%$ of the total population of Serbia and the second largest national minority. However, alternative data based on calculations by Roma NGOs and international organisations indicate that there are around 350,000 Roma in Serbia, with the estimated number of Roma children aged o-18 being 144,000 (Bennett, 2012).

\section{Pre-primary education for Roma children: access and quality}

Pre-primary education in Serbia is organised for children aged from 6 months to 6.5 years. The preparatory preschool programme (PPP), for children aged from 5.5 to 6.5 years (in the last preschool year), is compulsory for all

2 In the present paper, the term "pre-primary" will be used rather than ECCE when referring to publicly subsidised provision for children under compulsory school age in Serbia, because it corresponds more adequately to national education policy and academic terminology (which generally refers to "preschool upbringing and education", and does not explicitly assumes the concept of "care"). 
children, while nurseries (for children aged o-3) and kindergartens (for children aged 3-5) are voluntary.

The free-of-charge PPP was introduced in 2010 (The Law on Preschool Education, 2010) with the aim of providing an equal start for disadvantaged children at the beginning of their schooling. Attending a PPP should support Roma children in overcoming the language barrier, increase enrolment in the first grade of primary school, and decrease enrolments in special schools. However, some of the greatest challenges for the implementation of the PPP are the lack of capacities of preschool institutions (PI) and the lack of disaggregated data on Roma children (Baucal \& Stojanović, 2010).

The latest results of the Multiple Indicator Cluster Survey 4 (MICS) (UNICEF, 2011) show that the percentage of Roma children covered by pre-primary education is significantly lower than in the general population of children, as the following data illustrate:

- $15.03 \%$ of the general population of children are enrolled in nurseries, compared to less than $2 \%$ of Roma children (Bennett, 2012);

- $44 \%$ of the general population of children are enrolled in kindergartens, compared to only $8 \%$ of Roma children living in settlements (UNICEF, 2011);

- $\quad 97 \%$ of the general population of children enrolled in the first grade of primary school attended a PPP in the previous year, compared to $78 \%$ of Roma children living in settlements (UNICEF, 2011).

Although the enrolment of Roma children in pre-primary education is lower than in the general population of children, it is important to stress that the coverage of Roma children has increased significantly in the last five years. The results of MISC 3 show that in $20054 \%$ of Roma children were enrolled in kindergartens (UNICEF, 2006), while only $45 \%$ of Roma children were enrolled in a PPP (Living Standards Measurement Study, 2008). This increase is obviously the result of the introduction of new laws and strategies in the area of Roma education, and the implementation of numerous measures, such as the work of health mediators.

Concerns are, however, raised about the quality of the PPP. As pointed out in an OECD report (2006), in cases where early education services are regarded as a downward extension of the school system, rather than as a system specifically designed to meet the needs of young children, provision may be inappropriate, with formalised teaching of large groups relying too heavily on didactic approaches, exaggerated emphasis on targets and testing, and rigid regimes taking place in unsuitable spaces (OECD, 2006). Moreover, some studies confirm that effective early education programmes focusing on developing children's general 
cognitive abilities have more impact on later-life outcomes than those focusing on early literacy and numeracy, which result in more time-limited outcomes only at school (Chambers et al., 2010).

Therefore, even for some of the Roma children included in a PPP, the benefits seem doubtful. Case studies point to the "schoolification" of work with preschool children. PPP staff (consisting of primary school teachers and kindergarten teachers) are using content and instruction strategies more suitable for school than for kindergarten, such as teaching children to read and write, activities lasting for 30 minutes, and demands placed on children similar to those in school, including doing homework (Pešikan \& Ivić, 2009).

The key factor that contributes to the quality of the PPP is the pre-service education and in-service training of staff who carry out the PPP. The challenges are greater in environments where the PPP is conducted by school teachers, because kindergarten teachers are better prepared for working with preschool children due to their pre-service education. However, the PPP is frequently conducted by young kindergarten teachers without the sufficient experience, knowledge and competencies necessary for programme adjustments to disadvantaged children. More experienced kindergarten teachers avoid working in a PPP, because it covers only $75 \%$ of working hours, and therefore results in a lower salary (Pešikan \& Ivić, 2009, p. 27).

\section{Housing of Roma children: growing up in an environment of poverty}

The issue of education of Roma children and their under-representation in pre-primary education, particularly in kindergartens, can hardly be addressed without taking into consideration the extremely poor housing conditions and degraded environmental surroundings in which they grow up. The poverty level for Roma children is a especially high: $67 \%$ of children from Roma settlements are poor, and $62 \%$ of Roma households with children are living below the poverty line (UNICEF, 2007). According to the recent UNICEF study Women Motherhood Early Childhood Development (UNICEF, 2011), poverty increases family stress. Studies show that in households below the poverty threshold, one in four mothers of infants experiences moderate-to-severe levels of depressive symptoms. When mothers are depressed, children are less likely to receive adequate nutrition or preventative healthcare (UNICEF, 2011).

Fifty percent of the Roma population in Serbia live in the 573 Roma settlements scattered throughout the country. Of these settlements, $44 \%$ are slums: favela-like settlements, in shelters patched together out of mud, cardboard, metal sheets and plastic. According to the official definition, these settlements are 
"illegal", which means that their inhabitants do not have building permits, planning documents or regulated property issues. These settlements lack basic infrastructure: it is estimated that $35 \%$ do not have a water system, $65 \%$ do not have a sewage system, $45 \%$ do not have proper streets, and around $10 \%$ do not have an electricity supply network. The slums are overpopulated, with a low number of housing units per family and limited or no access to public services, public transportation, kindergartens and schools (Strategy for the Improvement of the Status of Roma in the Republic of Serbia, 2009, pp. 16-17). Therefore, 24\% of Roma parents state the distance to preschool facilities and the lack of transportation to kindergartens as reasons for not enrolling their children in kindergartens (UNICEF, 2011). Roma settlements are often located under bridges, squeezed between factories, in the dump areas, or other degraded sites. Members of mainstream society, including staff of various state services, rarely visit Roma settlements defined as ghettoes (Mitrović, 1992).

How does living in Roma settlements influence the health and development of young Roma children? According to the preliminary results of MICS 4 (UNICEF, 2011), health conditions of Roma children growing up in a slum environment are significantly worse than in the general population. Some of the striking results are:

- the Roma infant mortality rate (IMR) is estimated at 14 per thousand live births, and the probability of dying under the age of five is 15 per thousand live births, whereas, on the level of Serbia as a whole, IMR and the mortality rates of children under the age of five stand at 7 and 8 respectively per thousand live births;

- the nutritional status of Roma children is poor and malnourishment is several times higher than the national average: $6.6 \%$ of Roma children are underweight, compared to $1.6 \%$ of the general population, and $23.6 \%$ are stunted, compared to $6.6 \%$ of the general population;

- $\quad$ in the Roma population, $10.2 \%$ of infants have a low birth weight (less than 2,500 grams at birth), which is more than twice as high as in the general population $(4.8 \%)$;

- $\quad$ in Roma settlements, $14 \%$ of children under five years of age had had diarrhoea in the two weeks preceding the survey, compared to $7 \%$ in the general population; $18 \%$ of children aged 0-59 months in Roma settlements were reported to have had symptoms of pneumonia, compared to $5 \%$ in the general population.

These data clearly show that the health and early development of Roma children is not adequately supported. As Bennett (2012) points out, childhood 
is a critical stage, during which extreme poverty and malnutrition have lasting negative effects on subsequent health and development. "Unnecessarily high mortality rates should not leave indifferent any society that is based on human rights and social justice. Neither should the effects of ill-health and early malnutrition in children who survive be a matter of indifference. Infant malnutrition and stunting strongly impact on cognitive development and education attainment" (Bennett, 2012, pp. 34-35). It is obvious that there is a strong need to support Roma maternal and infant nutrition and health. Such support should begin before childbirth and continue throughout early childhood.

In addition, Roma mothers lack both support and information regarding health issues in the prenatal and postnatal periods. The majority of women from focus groups are convinced that they do not need advice about infant care, since they already know how to take care of a baby. Young Roma mothers $(16 \%$ of Roma girls in Roma settlements are married before 15 years, UNICEF, 2011) rely on traditional knowledge and advice from older women within the family and social network. One possible consequence is that young Roma mothers do not have enough knowledge regarding children's health, nutrition and vaccinations. When the mother is poor, illiterate and has limited access to information on health issues, she is less likely to have sufficient opportunities and awareness to ensure her child's optimal health and nutritional status (UNICEF, 2011). Although public nurses are obliged to visit Roma women in settlements - and do so in $80 \%$ of cases (UNICEF, 2011) - for young, uneducated Roma mothers this might not be enough. Just as young disadvantaged children need more years of early education, young Roma mothers living in shacks without water and electricity need more visits and outreach from public health services.

\section{Barriers to the access of Roma children to pre-primary education}

The issue of barriers to the inclusion of Roma children in pre-primary education is a complex one because it comprises numerous interlinked and overlapping factors that contribute to exclusion, disadvantage and ethically unacceptable inequalities in pre-primary education (Macura-Milovanović et al., 2013). Some of the major barriers to access and equitable participation of Roma children in preschool education in Serbia, indentified in various research and reports (Bennett, 2012; Macura-Milovanović et al., 2013; Open Society Foundations, 2007; UNICEF, 2007, 2011) are: the poverty of Roma families; majority discrimination and prejudice towards Roma; the lack of intercultural provision; insufficient inter-sectorial cooperation; the under-developed network of 
preschool institutions and the absence of kindergartens in Roma settlements.

\section{Lack of financial support for disadvantaged children}

The poverty of Roma parents, e.g., the lack of financial support for children at potential educational disadvantage, is one of the major causes of the low coverage of Roma children with pre-primary education. Roma children fail to attend kindergarten due to financial reasons in $38 \%$ of cases, while in the general population this is true in only $12 \%$ of cases (UNICEF, 2007). However, even the free-of-charge compulsory PPP contains hidden costs, e.g., for didactic materials that parents are obliged to buy. In addition, poor Roma families cannot afford the costs of childrens' hygiene and clothes, as the following statement by a Roma mother illustrates: "Who can pay for kindergarten? Books are expensive, and children need clothes, shoes, snacks... everything has to be paid for. I can't earn for everything by myself, I don't have money to pay even for electricity. I know that it would be better for children to go to kindergarten and to learn something. But I can't help it, that is our destiny" (Živković, 2012, p. 34).

\section{Discrimination against Roma}

Discriminatory behaviours towards Roma in the field of pre-primary education are not always easily recognised, as in cases of the denial of Roma children's access to kindergartens or giving false information to Roma parents. For example, Roma parents are told that there are no available places in PIs, are advised to send their children to other, often remote, locations, and that attending kindergartens needs to be paid monthly per child (although according to the Law on Preschool Education, 2010, underprivileged children have priority for enrolment). Uneducated Roma parents, who are not informed about their rights but are aware of discrimination and negative attitudes towards them and their children, easily abandon efforts to enrol their children in kindergartens, as the following statement of Roma mother illustrates: "Who am I? I am nobody and nothing. People (the majority population) don't see us, they won't talk with us... and who cares if Gypsy children don't go to kindergarten? That is normal here, and they won't accept us" (Živković, 2012, p. 45).

In other cases, discriminatory behaviour of kindergarten staff and non-Roma parents towards Roma children is openly demonstrated. In their study, Pešikan and Ivić (2009) refer to such a case of discriminatory behaviour towards Roma children, in which non-Roma parents, dissatisfied with the high number of Roma children enrolled, refused to bring their children to 
kindergarten. The problem was "solved" in the following way: Roma children were transferred to other kindergartens, irrespective of how much further they were from their place of residence. Even though there was an appeal for official intervention, the city authorities failed to respond or even answer the appeal (Pešikan \& Ivić, 2009, p. 23). Roma parents and children suffer deeply when they experience discrimination from teachers and/or peers. As Pantić, Ivošević and Closs argue, "Teachers who, knowingly or unknowingly behave exclusively and in discriminative ways must either be unaware that they are modelling intolerance and injustice for their pupils, or they must believe that their views are justified. Neither is acceptable" (Pantić, Ivošević, \& Closs, 2010, p. 90). The behaviour of discriminative teachers models attitudes of majority children towards their minority peers, possibly contributing to the latter group's social and educational exclusion.

\section{Lack of intercultural provision in preschool institutions}

The lack of intercultural provision in PIs is, on a concrete level, manifested through a failure to introduce Roma culture, e.g., signs and information in Romani language, as well as content regarding tradition, customs, culture and language. However, as childrearing is inevitably linked to culture, minority parents and children need to be reassured that they are fully entitled to retain their culture, language and cultural practices, and that these will be respected by majority staff and children within PIs.

On a more subtle, symbolic level, the lack of intercultural provision is reflected by the domination of the values and norms of mainstream society. Kindergarten teachers' perception of Roma parents' behaviour reveal concealed or open criticism of Roma parent's parental competencies. Negative attitudes towards Roma children and parents are illustrated in statements (shared by many teachers in primary schools), such as the following: "Roma parents are not motivated to send their children to the PPP... parents do not get involved in the work of the PPP... children have no support at home, many Roma parents enrol their children only because the PPP is compulsory" (kindergarten teacher, reported by Pešikan \& Ivić, 2009, p. 34). However, the majority of the female respondents in a UNICEF study (2011) were very interested in sending their children to preschool or alternative early childhood development centres run by NGOs, as they were aware of the benefits of preschool education.

The above quote illustrates a common perception of problems in the education of Roma children by members of the majority population. They judge the behaviour of Roma even though they have little knowledge and/or 
understanding of people living in extreme poverty, whose priorities are directed at meeting the basic needs of food, clothing and health, as well as the physical safety of children in the hostile environment of the slums. The RECI Report cites Vandenbroeck, who reported a similar belief regarding immigrant parents in Belgium, highlighting a tendency within the majority population to culturalise the 'deviant' behaviour of minority groups, e.g., "Immigrant parents don't like to send their children to services before the age of four". Vandenbroeck recommends less culturalisation of motive but more culturalisation of the programmes in which immigrant and ethnic children are enrolled (Bennett, 2012, p.42).

In the conflict between the values and models of childrearing in the family and in PIs, some Roma children may drop out, as the following statement by a Roma father illustrates: "My youngest daughter is three years old. We enrolled her in kindergarten, but she does not want to go. I can't force her to go, she refuses any company except us (father and older sisters). I would prefer her to attend, but she doesn't want to, she cries all the time." (Živković, 2012, p. 36).

The lack of intercultural provision is also reflected in the intentions of kindergarten teachers to "mend" Roma children in a way that corresponds to their own implicit ideas about "good" and "well mannered" children. However, the ideas of kindergarten teachers about education and childrearing may differ significantly from those of Roma parents. Rosenthal (1999) argues that minority parents rightly observe discrepancies between socialisation practices in PIs and their own socialisation goals. According to Farran (2000), this problem could be dealt with by organising preschool education that better matches the families' childrearing goals and values, and by employing staff from the minority communities. Minority families have to deal with a great deal of stress regarding family income, unemployment, daily childrearing and the neighbourhood in which they live. Trying to meet the requirements of personal involvement in an education programme, or observing the time schedule and rules of the PI, may be an extra burden for them.

\section{Insufficient inter-sectorial cooperation}

Meeting the needs of preschool children assumes the interconnection and coordination of different services and ministries (education, health, social protection). Insufficient cooperation between ministries (who have different goals, different personnel, different modes of intervention, different offices and services - all working for the same children) leads to a fragmented approach in meeting the educational, health and social protection needs of Roma children. 
What occurs in practice is both duplicated services and large service gaps.

In some cases, lack of cooperation and complex administrative procedures prevent or prolong access to PIs and schools, as well as to personal documents, social benefits, etc. This leads to demotivation and a loss of Roma trust in the goodwill and ability of state institutions to provide them with the necessary assistance and support. The result is that not all parents want their children to be enrolled in PIs. From their perspective, pre-primary education seems either unavailable in general, or unavailable specifically to their family or community.

Proper information about the availability of pre-primary education services - about vacant places for Roma children in kindergartens, transport from home to the PI, financial support for hidden costs, assurance for Roma parents that their children will be treated adequately and that they are welcome - are problems that Roma parents see as obstacles to the enrolment of their children in the system of pre-primary education (UNICEF, 2011). However, these problems could be resolved through cooperation and the clear distribution of duties and responsibilities among various ministries and the relevant services.

\section{Underdeveloped network of preschool institutions}

Last but not least, there is the barrier of the underdeveloped network of PIs. Due to the lack of buildings and employees, the network of preschool institutions can not meet the need for pre-primary education in the whole territory of Serbia. Therefore, the coverage of children is insufficient in the areas in which it is most needed, as is the case of Roma settlements. Furthermore, a weak network prevents the realisation of the PPP as a part of compulsory primary education (Ivić et al., 2010, p. 68).

Finally, a special challenge arises where there are no kindergartens available, as is the case in isolated Roma settlements and slums. In the following subsection, one potential solution for overcoming the barriers listed above will be discussed.

\section{Community-Based Programmes in Roma Settlements}

What can be done to provide pre-primary education to Roma children living in poverty and in isolated settlements? One of the solutions proposed in the RECI Overview Report is to conceive a comprehensive, multidimensional intervention model that integrates health, care and education services for the communities where Roma mothers and children live. Such a service model 
should include prenatal and postnatal health, parenting and adult education, and play and stimulation programmes for toddlers, conducted in the relevant Romani dialect, with a particular focus on the education of girls. This could be achieved by the local health and paediatric services. As the RECI Overview Report stresses, such a model could be realised only in consultation with Roma communities and NGOs, and with the help of Roma health and education assistants (Bennett, 2012, p. 62).

Bearing in mind the health and living conditions of young Roma children in slums, as described above, it seems obvious that such community-based programmes are desperately needed for children until the age of three, four or five years (Bennett, 2012, p. 58). However, it is important to stress that programmes in Roma settlements could only be justified as a transitory solution, i.e., as the first step towards subsequent enrolment of Roma children in kindergartens and the PPP, and their full education and social inclusion. In other words, these programmes could contribute to the health and development of young Roma children before their inclusion in desegregated programmes in preschool institutions.

Although such a solution is contentious, both from Roma and nonRoma perspectives, due to the risk of further segregation of Roma children, it seems that, for the time being and in the circumstances as they are, this could be the only solution. Under the current circumstances, where housing segregation in Roma slums already exists, and while Roma children are very young, their regular attendance in PIs is unlikely if the institutions are located far from the settlements, as is the case at present. This is especially true during cold winters and when there is no money or public transportation. "In these cases, services need to be brought to where people are, with the support and input of the local community. This manner of programming keeps the child within the family circle and has the advantage of raising community knowledge and, if properly organised, of providing local employment" (Bennett, 2012, p. 58). This viewpoint is echoed by a Roma NGO leader: "I think that work in the local community should be conducted with children between o and 5 years of age, to start from birth, both with parents and children. Practically, when the time comes for the PPP, Roma children would be as ready for school as any other non-Roma child and parent. And I think that this would be far cheaper, from a financial point of view. This would involve a global approach to Roma families and the Roma community, by forming multi-functional centres in Roma settlements".

The features of a comprehensive model can be found in certain community-based programmes implemented in the last decade by Roma and nonRoma NGOs in various districts throughout Serbia. The following list is by no means exhaustive: 
- The project Kindergarten as a Family Centre in Roma Settlements was carried out in 10 locations (1997-2005, supported by the Open Society Institute, Fund for an Open Society in Serbia). Roma children (3-7 years old) participated in high quality education programmes based on the Step by Step methodology, in newly built kindergartens in Roma community centres. Subsequently, all of the children from these Roma groups were enrolled in mainstream schools. Furthermore, efforts were made for kindergartens in local communities to be integrated into the regular school system (Open Society Foundations, 2007, p. 37).

- The project Slum Upgrading Model in Deponija Roma Enclave, implemented by the NGOs Society for the Improvement of Local Roma Communities (SILRC), Roma Hart and Bibija - Roma Women Centre (funded by the EC, NOVIB and UNICEF, 2000-2004) in Belgrade. This project consisted of several programmes concerning education, housing, health, women's programmes and employment, all carried out in the settlement. Once installed, education programmes were attended daily by around 100 children aged 3 to 15 years. The majority of preschool and school-age children were subsequently included in primary school (Macura-Milovanović, 2006).

- From 2002, SILRC implemented the project Improvement of Roma Education in Southern Serbia: Developmental Education Centres (supported by UNICEF in cooperation with the Ministry of Education and local municipalities) in nine of the poorest towns in the south of Serbia. Some of the most important results of the projects relate to the high enrolment rate of Roma children in the PPP, the small percentage of drop-out after the $4^{\text {th }}$ grade of primary school, and the large percentage of children enrolled in secondary education (Baucal \& Stojanović, 2010, p. 235).

There are several interrelated components of community programmes that contribute to their efficiency: establishing and maintaining trusting relationships with Roma children and parents, a Roma community approach, and the high quality of kindergarten programmes (Macura-Milovanović, TatićJanevski, Kovačević, \& Arsić, 2010).

The aforementioned examples of successful programmes implemented in settlements illustrate the huge efforts of NGOs, who aim to compensate for the missing link: the complex trust-building process between institutional services and the Roma. Only trusting Roma parents will accept the advice of kindergarten teachers regarding the nurturing, health, learning and development of children. Therefore, kindergarten staff should be trained to actively listen to 
parents (their needs and feelings, fears and worries), in order to establish a basis for trusting relationships.

There are no uniform solutions for all situations and each context, no ready-made recipes. It is necessary to adjust state services to Roma children and parents (not vice versa), to be creative and willing to search for the best possible solutions. This is why it is necessary to establish direct contact with Roma families in settlements, e.g., a community approach. Instead of the insensitivity and arrogance of imposing the values and standards of mainstream society, solutions should be created with Roma, who could choose among the alternatives offered in a clear and sincere manner, with a detailed explanation of the consequences of any alternative chosen by Roma. Neither children nor parents can be regarded simply as clients of a preschool or other institution pretending to have an exclusive claim to knowledge of what is right or wrong, and rejecting the very idea of the necessity of adapting to Roma needs.

The high quality of kindergarten programmes for Roma children is related to low child/staff ratios, experienced, well-trained teachers who are capable and motivated to maintain social and instructional interactions with children that foster their academic, language and social competencies. The continuity of children's experience is significantly improved when parents and kindergarten teachers adopt consistent approaches to socialisation, daily routines, child development and learning. In order to avoid assimilation of Roma children, continual reconstruction of the daily practice of kindergartens and intensive interaction with children and families is needed.

\section{Conclusions}

With funding representing only $0.43 \%$ of GDP, pre-primary education in Serbia is underfunded (Bennett, 2012) and underdeveloped, despite the proven benefits to the child, the economy and society. Increasing coverage of Roma children in pre-primary education is an undertaking that is unquestionably necessary but very complex. Even though the state creates a new social and political context through the adoption of new education laws and strategies, trying to meet the needs of marginalised groups and individuals, in practice, institutions fail to utilise available potentials in order to efficiently solve the accumulated problems. If Roma children are to have a fair start in life, the state and its institutions should take the responsibility to help all children achieve their full potential, whatever their background or circumstances. The state and its institutions should take actions to support disadvantaged children, because it is crucial to help them to fulfil their potential. 


\section{What actions are needed to support disadvantaged children?}

It is unquestionable that the best solution is to include all Roma children in state preschool institutions at the earliest possible age, in high quality programmes conducted by interculturally sensitive and motivated staff ready to reach out, cooperate and build trust with Roma parents. Research data are clear: the lack of high quality early childhood services results in more harm than good for children. The RECI Overview Report conclusion, inter alia, is that a free place in kindergarten should be provided for at least two years to every child coming from an 'absolute poverty' background, and disadvantaged Roma parents should be provided with the necessary support to enable their children to attend programmes continuously. In addition, extra funding is needed in order to achieve the highest quality of kindergarten programmes (Bennett, 2012, p. 47). Both suggestions assume an increase in the percentage of GDP allocated to pre-primary education. As already pointed out, increased investment today results in greater gains in the future, not only for the Roma community but for the whole society.

It has already been stressed that the PI network is underdeveloped, that present capacities are insufficient for all children, and that there are no PIs in Roma settlements. What should be done with the thousands of Roma children who are out of reach in the period until the state builds sufficient PI buildings, constructs sufficient social housing for Roma families, and provides sufficient employment for Roma parents if they have to cover the hidden costs of 'free-of-charge pre-primary education? The suggestion presented here is the establishment of community-based programmes in Roma settlements, as a less expensive and real possibility to overcome the numerous obstacles present today. Moreover, high quality programmes depend on the staff who realise them, on their experience and education, rather than on the sites where these programmes are realised.

Finally, the suggested model assumes the resolution of problems there where they appear: within the Roma settlements themselves. There is a need to strengthen not only pre-primary education services for Roma families with young children, but also to strengthen services for prenatal care, infant health, outreach health nursing, social services and parental involvement.

\section{References}

Baucal, A., \& Stojanović, J. (2010). Indicators of equal access for quality education for Roma, Belgrade: Fund for Open Society Serbia. 
Bennett, J. (2012). Roma Early Childhood Inclusion. The RECI Overview Report. Open Society Foundations, Roma Education Fund and UNICEF. Retrieved January 312013 from http://www. opensocietyfoundations.org/sites/default/files/Roma-Early-Childhood-Inclusion-Report-20120813.pdf Chambers, B., Cheung, A., Slavin, R., Smith, D., \& Laurenzabo, M. (2010). Effective early childhood education programmes: A best-evidence synthesis. CfBT Education Trust. Retrieved January 312013 from http://www.cfbt.com/

European Commission. (2009). Early Childhood and Care Education: Key lessons from research to policy makers. An independent report submitted to the European Commission by the NESSE networks of experts. Retrieved January 312013 from http://www.nesse.fr/nesse/activities/reports/ecec-report-pdf Eurydice Network. (2009). Tackling Social and Cultural Inequalities through Early Childhood Education and Care in Europe. Brussels: Education, Audiovisual and Culture Executive Agency. Farran, D. C. (2000). Another decade of intervention for children who are low income or disabled: What do we know now? In J. P. Shonkoff \& S. J. Meisels (Eds.), Handbook of early childhood intervention (Second edition; pp. 510-548). Cambridge, England: Cambridge University Press. Heckman, J. J. (2006). Skill formation and the economics of investing in disadvantaged children. Science, (5728), 1901-1902.

HighScope. (2004). Transcript of audio news briefing on the HighScope Perry Preschool study age 40 findings. Retrieved January 312013 from http://www.highscope.org/Content.asp?ContentId=253 Ivić, I., Pesikan, A., \& Jankov, R. (2010). Report of Consultants on the DILS (Delivery of Improved Local Services) Projects in Education. Credit No.7510-YF. Belgrade: Ministry of Education and Science of the Republic of Serbia.

Leseman, P. P. M. (2009). The impact of high quality education and care on the development of young children: review of the literature. In Tackling Social and Cultural Inequalities through Early Childhood Education and Care in Europe (pp. 17-49). Brussels: Education, Audiovisual and Culture Executive Agency.

Lynch, R. G. (2005). Early childhood investments yields big payoff. Policy Perspectives. San Francisco, CA: WestED.

Living Standards Measurement Study Serbia 2002-2007 (2008). Belgrade: Statistical Office of the Republic of Serbia, The World Bank \& Department for International Development.

Macura-Milovanović, S. (2006). Otroci iz Deponije. Pedagoški vidiki vključevanja romksih otrok v izobraževalni sistem-analiza akcijskega eksperimenta. Ljubljana: Faculty of Education. Macura-Milovanović, S., Tatić-Janevski, S., Kovačević, M., \& Arsić, M. (2010). Ogled izbliza: socijalnopedagoški aspekti rada sa romskom decom i roditlejima u naselju Deponija. [The perspective of social pedagogical work with Roma children and parents in the Deponija settlement]. In S. Macura Milovanović (Ed.), Socijalna pedagogija u nastajanju - traženje odgovora na problem društveno isključenih grupa (pp. 191-209). Jagodina: Faculty of Education in Jagodina.

Macura Milovanović, S., Batarelo Kokić, I., Džemidžić Kristiansen, S., Gera, I., Ikonomi, E., Kafedžić, L., Milić, T., Rexhaj, X., Spasovski, O., \& Closs, A. (2013). Dearth of early education experience: a significant barrier to educational and social inclusion in the Western Balkans. International Journal 
of Inclusive Education. doi:10.1080/13603116.2012.756948

McClelland, M. M., Acock, A. C., \& Morrison, F. J. (2006). The impact of kindergarten learningrelated skills on academic trajectories at the end of elementary school. Early Childhood Research Quarterly, 21, 471-490.

Mitrović, A. (1992). Romska staništa u Srbiji. [Roma settlements in Serbia]. Belgrade: Godišnjak instituta za socijalnu politiku.

OECD. (2006). Starting Strong II: Early Childhood Education and Care. Paris: OECD.

Open Society Foundations. (2007). Equal Access to Quality Education For Roma, Serbia: Vol. 1: Bulgaria, Hungary, Romania, Serbia. Monitoring report. Open Society Institute, EU Monitoring and advocacy Programme. Education Support Programme. Roma Participation Programme.

Pantić, N., Closs, A., \& Ivošević. V. (2010). Teachers for the future. Teacher development for inclusive education in the Western Balkans. Torino: European Training Foundation.

Pešikan, A. \& Ivić, I. (2009). Obrazovanjem protiv siromaštva: Analiza uticaja uvođenja pripremnog predškolskog programa u Srbiji, Vlada Republike Srbije, Tim potpredsednika Vlade za implementaciju SSS i Ministrastvo prosvete RS.

Rosenthal, M. K. (1999). Out-of-home child care research: A cultural perspective. International Journal of Behavioral Development, 23(2), 477-518

Save the Children. (2001). Denied a future? Summary. London: Save the children.

Serbia Multiple Indicator Cluster Survey MICS 4 2010. (2011). Preliminary Findings. Statistical Office of the Republic of Serbia and UNICEF. Retrieved January 312013 from http://www.unicef.rs/novosti/ istrazivanje-visestrukih-pokazatelja-stanja-i-polozaja-dece-i-zena-u-srbiji-ukazuje-na-napredak.html Serbia Multiple Indicator Cluster Survey MICS 32005 - Monitoring the situation of children and women. (2006). Statistical Office of the Republic of Serbia, Strategic Marketing and UNICEF.

Retrieved January 312013 from http://www.childinfo.org/files/MICS3_Serbia_FinalReport_2005-06_ Eng.pdf

Sylva, K., Melhuish, E., Sammons, P., Siraj-Blatchford, I., \& Taggart, B. (2004). The Effective Provision of Preschool Education (EPPE) Project: Findings from Preschool to end of Key Stage 1. London: Institute of Education.

Strategy for the improvement of the status of Roma in the Republic of Serbia (2009). Belgrade: The Ministry of Human and Minority Rights.

The Law on Preschool education (2010). National Assembly of the Republic of Serbia. Official Gazette of the Republic of Serbia, No 18/2010.

UNICEF. (2007). The state of children in Serbia 2006. Poor and excluded children. Belgrade:

UNICEF. Retrieved January 312013 from http://www.unicef.org/serbia/State_of_Children_in_

Serbia_2006_1-56(1).pdf

UNICEF. (2011). Women Motherhood Early Childhood Development. Exploring the question of how poor Roma women's status and situation influences children's survival, growth and development. Retrieved January 312013 from http://www.unicef.org/serbia/Women_Motherhood-o7-21-2011-final$\mathrm{WEB}(3) \cdot \mathrm{pdf}$ 
Živković, V. (2012). Roma parents' perception of barriers to inclusion of Roma children in pre-primary education. [Percepcija roditelja romske nacionalnosti o preprekama uključivanju dece u sistem predškolskog obrazovanja i vaspitanja]. MA thesis. Faculty of Education in Jagodina, University of Kragujevac.

\section{Biographical note}

Sunčica Macura-Milovanović (Serbia) is an assistant professor of Inclusive Education at the Faculty of Education in Jagodina, University of Kragujevac, Serbia. Her research work includes investigating the education of Roma children in Serbia and methods of instruction in multicultural primary school classes. She is currently researching the attitudes of student teachers towards inclusive education. 